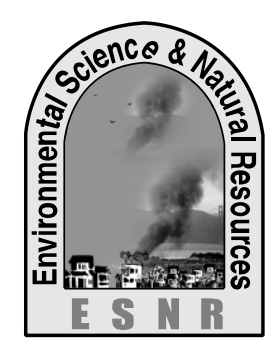

\title{
Nutritional Status of Women Living at South-west Coastal Belt of Satkhira Bangladesh
}

\author{
C. Moumita* , B. K. Biswas and H. Muktadir ${ }^{1}$ \\ Department of Environmental Science and Technology, Jessore University of Science and \\ Technology, Jessore-7408, Bangladesh \\ ${ }^{1}$ Department of Environmental Science, Bangladesh Agricultural University, \\ Mymensing-2202, Bangladesh \\ *Corresponding author: moumita_envsc@yahoo.com
}

\begin{abstract}
Malnutrition has long been regarded as a widespread public health problem especially in the poorest part of Bangladesh. For determining nutritional status of women living in South-West coastal belt of Bangladesh, in this regard, Shyamnagar Upazilla of Satkhira district was selected. A random questionnaire survey was conducted by pre scheduled structured questionnaire among the 6 villages from Gabura and Munshiganj union of the Shyamnagar Upazilla during November, 2012 to January, 2013. A total of 120 households (preferably women) were randomly selected from the six study villages based on mainly livelihood pattern of the households such as crop production, shrimp culture and Sunderbans depended activities. In the study area, about $54.17 \%$ women had BMI of 18.5-24.9 and mean body weight of $49.75 \pm 8.36 \mathrm{~kg}$. About $79.16 \%$ families had vegetable gardens around their houses and they were gardening mainly for consumption and additional income of the family. Most of the families could not afford to enough eat more egg, fish or meat after Aila occurred because of low availability due to soil salinity. Salinity caused many diseases; skin disease was one of them. About 28\% families bought food in credit and $20.14 \%$ respondents in Gabura and 31.59\% in Munshiganj paid their loan at Pohela Boishakh. They received treatment facilities for their health hazards from village doctors and public health centre during the period of disease occurred. This study concluded that salinity affect the livelihood and nutrition on the community of the coastal belt.
\end{abstract}

Key words: Bangladesh, Coastal belt, Nutrition, South-west, Women

\section{Introduction}

Malnutrition is a complex condition that could be influenced by multiple causes. Women became malnourished due to illness combined with inadequate dietary intake. Household's food insecurity, inadequate knowledge due to lack of education, lack of safe water and sanitation and poor health service could be considered as potential underlying causes that could lead to malnutrition (UNICEF, 1998). Access to safe water remains an extremely important global health issue. More than 2 billion people lived in the dry regions of the world and suffer disproportionately from malnutrition, infant mortality and diseases related to contaminated or insufficient water (WHO, 2000). Climate change was considered as one of the most serious threats to human health, food security, agriculture, fisheries, biodiversity, water, economic activities and other natural resources in coastal region (NCSA, 2007). Islam et al., (2006) discussed the issues of the coastal area had been adversely affected by the combination of natural hazards, man-made hazards and socio-economic activities, such as tropical cyclones and associated storm surge floods, river erosion, sea beach erosion, lack of adequate domestic water supply, arsenic contamination of groundwater, drainage congestion and water logging, saline water intrusion, soil salinity, conflict between shrimp farming and rice cultivation, scarcity of freshwater due to reduction of inflow to the rivers, degradation of ecosystems, deterioration of waterways, risk of sea level rise, remoteness of the area and inadequate infrastructural facility. Pena and Bacallao (2002) stated that poverty and nutrition were closely related, poverty leads to hunger, ill health and malnutrition. Nutritional status depended on food and nonfood items such as education and hygiene, practice. Low food security and food intake was one of the direct consequences of poverty;
Intra-household allocation was the final step in the chain of events that determines food availability to individuals, ultimately influencing the health and nutritional status (Esterik et al., 1997). Cooper (1991) stated that diarrhea spread most readily in environments of poor sanitation, poor socio-economic condition, deficiency in sanitary facilities, and improper disposal of human faces, insufficient supplies of potable water, poor personal hygiene, substandard housing and lack of health education. This study was a modest effect to examine the nutritional status, food consumption pattern of the women living in coastal community of South-West part of Bangladesh.

\section{Materials and Methods}

This study was conducted to Munshiganj and Gaburaunion in Shyamnagar Upazila (located between $21^{\circ} 36^{\prime}$ and $22^{\circ} 24^{\prime}$ north latitudes and between $89^{\circ} 00^{\prime}$ and $89^{\circ} 19^{\prime}$ east longitudes) of Satkhira district and total of 120 households (preferably women) who had above 18 years old were randomly selected during November, 2012 to January, 2013from the six study villages by flowing livelihood pattern (Table 1).

\section{Data collection and analysis}

Primary data were collected through questionnaire survey. Anthropometric measurement such as height and weight were measured by steel scale and weight machine respectively. The units of height and weight were taken as feet and kilogram. Questionnaire survey found to socio-economic status, food habit, food consumption pattern, and food source and many more. BMI (Body Mass Index) could be estimated by the following equation:

$$
B M I=\frac{\text { Bodyweight }(\mathrm{kg})}{\text { Height }\left(\mathrm{m}^{2}\right)}
$$

The nutritional status states an category of BMI as below 18.5 was underweight, 18.5-24.9 was normal 
weight, 25.0-29.9 was overweight and 30.0 and above was Obese (WHO, 2000). The survey data had been edited and coded manually and processed by MS EXCEL and SPSS version 16. Statistical methods such as frequency count, percentage, bar diagram, pie chart, box plot, one way ANOVA, cross table etc. were used for analysis.

Table 1. Selection of households from six villages on the basis livelihood pattern

\begin{tabular}{|c|l|l|l|c|}
\hline \multirow{2}{*}{ Sl. No. } & \multirow{2}{*}{ Union } & \multicolumn{1}{|c|}{ Village } & \multicolumn{1}{c|}{ Livelihood pattern } & Sample Size \\
\hline \multirow{2}{*}{1} & \multirow{2}{*}{ Munshiganj } & Harinarar & Crop (rice) dominated area & 20 \\
\cline { 3 - 6 } & & Munshigang & Shrimp farming area & 20 \\
\cline { 3 - 6 } & Chunkari & Area of Sunderbans depended livelihood pattern & 20 \\
\hline \multirow{2}{*}{2} & \multirow{2}{*}{ Gabura } & 10 No. Sora & Crop (rice) dominated area & 20 \\
\cline { 3 - 6 } & Dumuria & Shrimp farming area & 20 \\
\cline { 3 - 6 } & Chadnimukha & Area of Sunderbans depended livelihood pattern & 120 \\
\hline \multicolumn{2}{|c|}{ Total households } & 20 \\
\hline
\end{tabular}

\section{Results and Discussion}

\section{General information}

From the following table, it was observed that maximum $(33.33 \%)$ women were found less than 30 years. Only $4.17 \%$ women were aged above 70 years. Second highest about $28.33 \%$ women were in 30-39 years. Table 2 represented that most of the women (35\%) had no formal education, about $20 \%$ women were five passed. On other side $20 \%$ women were

Table 2. General information of the women in the study area

\begin{tabular}{|c|c|c|c|}
\hline Variable & $\begin{array}{c}\text { Number of } \\
\text { Respondents }\end{array}$ & Percentage & Mean \pm SD \\
\hline \multicolumn{3}{|c|}{ Age distribution (year) } & \\
\hline$<30$ & 40 & 33.33 & \\
\hline $30-39$ & 34 & 28.33 & \\
\hline $40-49$ & 27 & 22.5 & \\
\hline $50-59$ & 14 & 11.67 & $35.83 \pm 11.00$ \\
\hline $60-69$ & 3 & 2.5 & years \\
\hline$>70$ & 2 & 1.67 & \\
\hline Total & 120 & 100 & \\
\hline \multicolumn{4}{|c|}{ Educational Status } \\
\hline $\begin{array}{l}\text { No formal } \\
\text { education }\end{array}$ & 42 & 35 & \\
\hline Signature & 24 & 20 & \\
\hline Five pass & 24 & 20 & \\
\hline Eight pass & 6 & 5 & \\
\hline $\begin{array}{c}\text { Above S.S.C } \\
\text { pass }\end{array}$ & 24 & 20 & \\
\hline Total & 120 & 100 & \\
\hline \multicolumn{4}{|l|}{ Religious Status } \\
\hline Muslim & 101 & 84.17 & \\
\hline Hindu & 19 & 16.83 & \\
\hline Total & 120 & 100 & \\
\hline
\end{tabular}

\section{Monthly income}

From the survey result it was found that about $69.2 \%$ $(n=83)$ households were earned five to ten thousand TK per month. The mean monthly income of the households was 6987 TK. per month with standard deviation ( \pm 3290.20$)$ (Fig. 1 and 2). above S.S.C passed. Education influenced access to knowledge, increased opportunities of income, development of nutritional status, and to benefits and resources (WHO/SEARO, 2000). Among the total respondents about $84 \%$ women were Muslim and $16 \%$ women were Hindu.

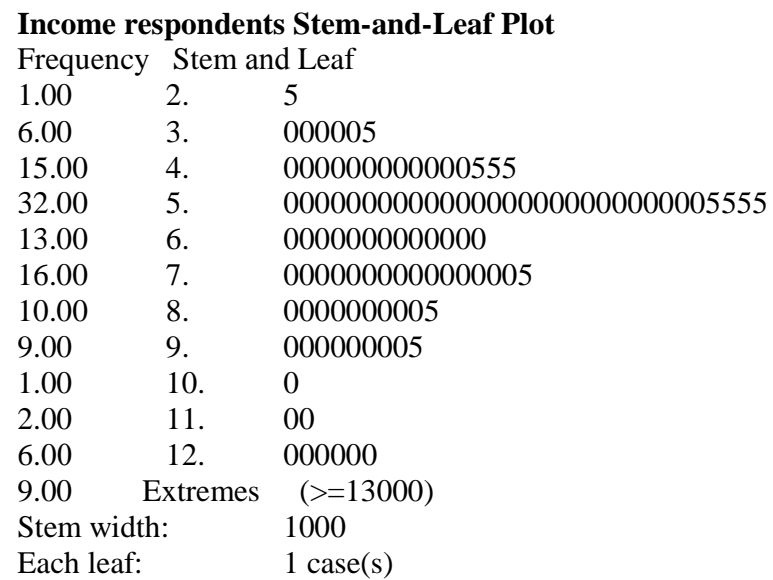

Fig. 1. Income respondents Stem-and-Leaf Plot

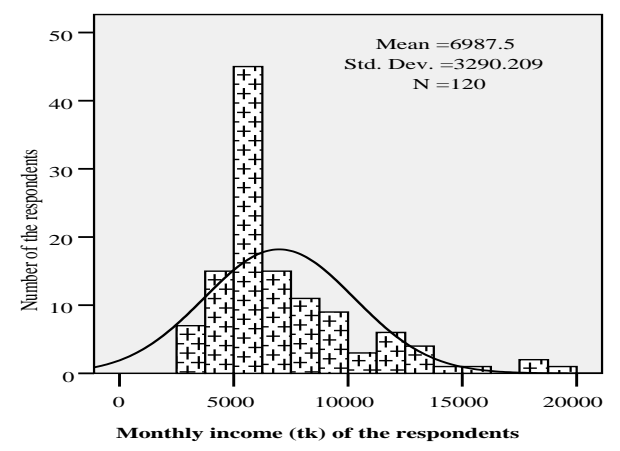

Fig. 2. Histogram of monthly income of households 


\section{Nutritional status}

\section{Height and weight of women}

The minimum and maximum height of the women were 177 years old and 123 yearsold respectively with mean \pm SD of height in $\mathrm{cm}$ was $142.46( \pm 10.41)$. The maximum, minimum and mean weight of the women was $77 \mathrm{~kg}, 32 \mathrm{~kg}$ and $49.75 \mathrm{~kg}$ respectively. The Boxplot shows that the weight of the respondents was

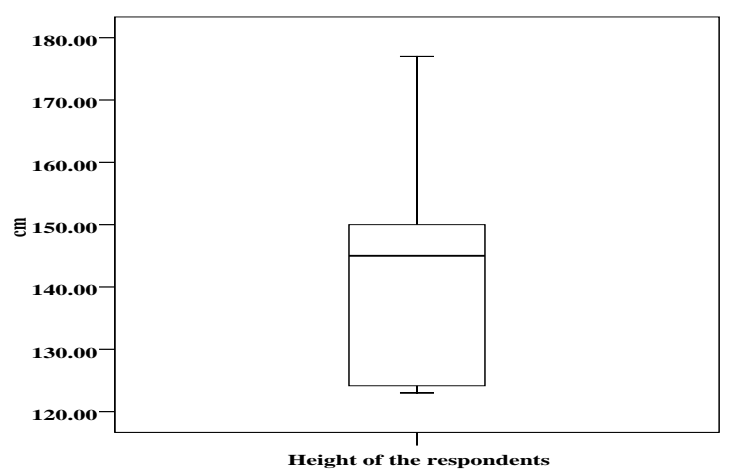

Fig. 3. Boxplot (height) of the women

\section{BMI of women}

The mean BMI of women was $23.52 \pm 4.37$ (SD) and it was indicated that about $12.50 \%$ of women in this area had a body mass index lower than 18.5 . About $54.17 \%$ women had normal BMI category where $21.67 \%$

\begin{tabular}{lll}
\multicolumn{3}{l}{ BMI Stem-and-Leaf Plot } \\
\begin{tabular}{lll} 
Frequency & \multicolumn{2}{l}{ Stem and Leaf } \\
2.00 & 15. & 25 \\
4.00 & 16. & 0589 \\
6.00 & 17. & 226778 \\
6.00 & 18. & 013779 \\
10.00 & 19. & 1223333577 \\
6.00 & 20. & 078899 \\
15.00 & 21. & 023444455677799 \\
10.00 & 22. & 2224457899 \\
13.00 & 23. & 0112256678888 \\
8.00 & 24. & 02258899 \\
11.00 & 25. & 12233444588 \\
4.00 & 26. & 2666 \\
6.00 & 27. & 111555 \\
2.00 & 28. & 44 \\
3.00 & 29. & 007 \\
6.00 & 30. & 033399 \\
4.00 & 31. & 6668 \\
1.00 & 32. & 2 \\
1.00 & 33. & 1 \\
2.00 Extremes & \\
Stem width: & 1.00000 \\
Each leaf: & 1 case(s)
\end{tabular}$(>=33.7)$
\end{tabular}

Fig. 5. BMI Stem-and-Leaf Plot positively skewed and median weight of the women were $49.5 \mathrm{~kg}$ (Fig. 3 and 4). The average height of these women was $144.45 \mathrm{~cm}$ in Gabura and $141.54 \mathrm{~cm}$ in Munshiganj, respectively.

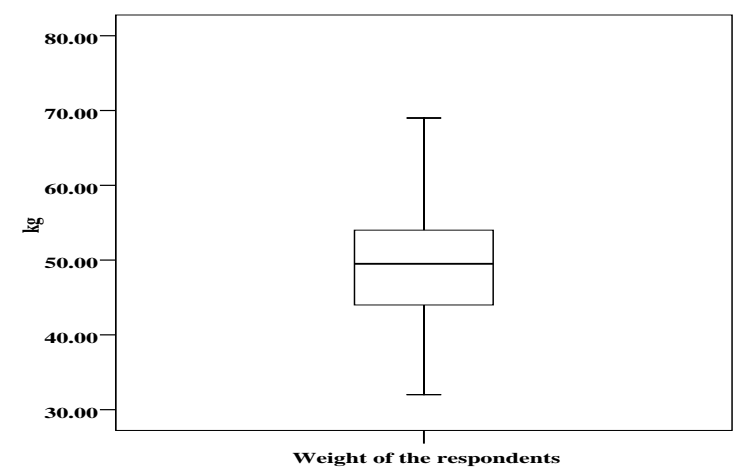

Fig. 4. Box plot (weight) of the women women were over weighted. The maximum and minimum BMI were 15.06 and 33.67 (Fig. 5 and 6).In Bangladesh nearly half of women were suffering from chronic malnutrition and BMI <18.5(NIPORT, 2009).

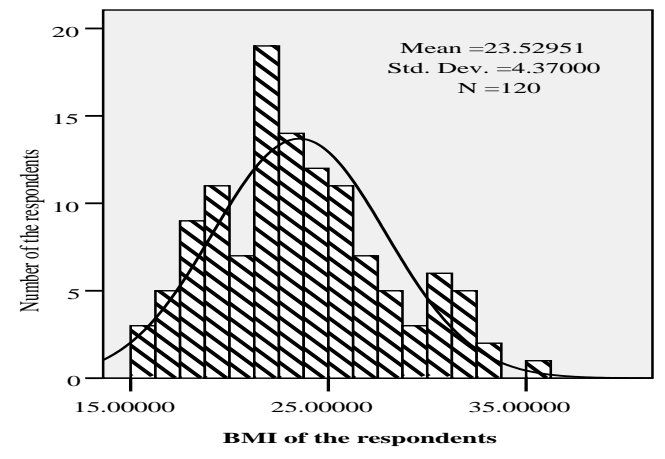

Fig. 6. Histogram of BMI of the women

\section{Relation with BMI and age of the respondents}

Table 3 showed one way ANOVA of BMI with the age of the respondents. BMI was categorized into four groups as less than $18.5,18.5$ to 24.9 and 25 to 29.9 and above 30. Group 1 had a mean age of $35.8( \pm 11.97)$ years, group 2 had a mean age of $35.59( \pm 11.55)$ years and group 3 had a mean age of $37.19( \pm 10.17)$ years and 4 had a mean age of $34( \pm 8.9)$ years. So, mean ages were not positively related with BMI groups. BMI of group 2 was insignificantly different from group 1 and group 3 was also insignificantly different from groups 4 at the level of $0.05(\mathrm{~F}=.26, \mathrm{p}=0.854)$. 
Table 3. One way ANOVA between BMI and age of the respondents

\begin{tabular}{|c|c|c|c|c|c|c|c|c|c|}
\hline \multirow[b]{2}{*}{ BMI category } & \multicolumn{3}{|c|}{ Age of respondents } & \multirow{2}{*}{ Source } & \multirow{2}{*}{$\begin{array}{c}\text { Sum of } \\
\text { Squares }\end{array}$} & \multirow{2}{*}{ df } & \multirow{2}{*}{$\begin{array}{c}\text { Mean } \\
\text { Square } \\
\end{array}$} & \multirow{2}{*}{$\mathbf{F}$} & \multirow{2}{*}{ Sig. } \\
\hline & $N$ & Mean & $S D$ & & & & & & \\
\hline less than 18.5 & 15 & 35.8 & 11.97 & $\begin{array}{l}\text { Between } \\
\text { Groups }\end{array}$ & 96.38 & 3 & 32.12 & \multirow{5}{*}{0.26} & \multirow{5}{*}{0.85} \\
\hline 18.5 to 24.9 & 65 & 35.69 & 11.55 & Within Groups & 14322.28 & 116 & 123.46 & & \\
\hline 25 to 29.9 & 26 & 37.19 & 10.76 & Total & 14418.66 & 119 & & & \\
\hline Above 30 & 14 & 34 & 8.19 & & & & & & \\
\hline Total & 120 & 35.83 & 11.007 & & & & & & \\
\hline
\end{tabular}

\section{Sources of food}

Fig. 7 indicated that most families in Gabura (42.85\%) and Munshiganj (52.22\%) depended on market for fish while household ponds provided $32.77 \%$ and $23.33 \%$ at Gabura and Munshiganj, respectively. Market provided the major vegetables in the study area and it was significant in Gabura (41.12\%) and Munshiganj $(59.40 \%)$. Supply of vegetable from homestead garden was $35.45 \%$ and $37.62 \%$ in Gabura and Munshiganj respectively for food security (Fig. 8). Hundred percent respondents had taken three meals a day. Most of the families did not eat more fish and meat after Aila because of low availability that was indirectly affected

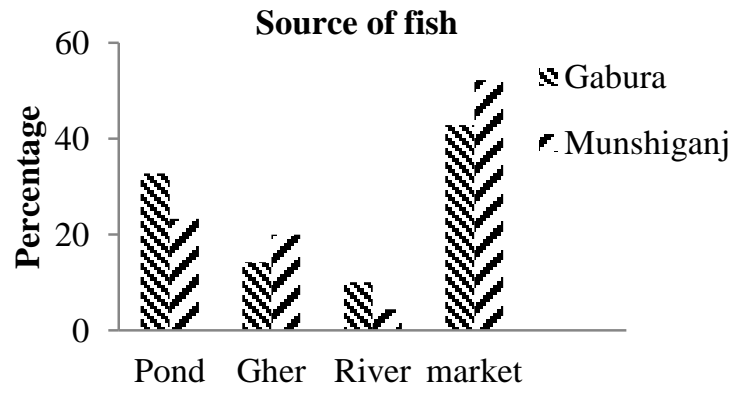

Fig. 7. Sources of fish for the households

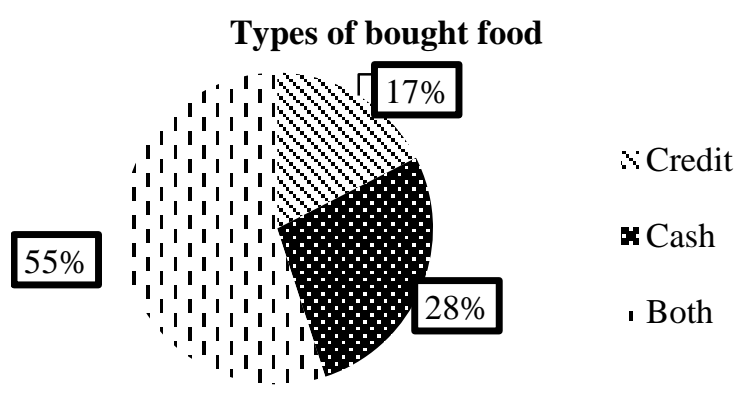

Fig. 9. Types of bought food of the households

\section{Consumption of food}

Table 4 represented that the respondents of this locality eat rice every day. They ate rice and vegetables in the morning. They ate vegetable 1-2 day in a week. They ate fish almost every day because fish was available here. Most of the households had own or leased gher for fish and shrimp cultivation. Because of fewer domestic animals, the problem of milk was being acute. They did not eat bread, milk every day but in special occasions by soil salinity. Availability of food at the household level varied considerably according to seasons, from place to place and from year to year that was related to socioeconomic. About $17 \%$ households bought food by cash and $28 \%$ respondents bought food by credit and $55 \%$ families bought food by both cash and credit (Fig. 9).They paid their due loan (money) weekly, monthly, yearly and in Pohela Boishakh. About 20.14\% respondents in Gabura and $31.59 \%$ in Munshiganj paid their loan at Pohela Boishakh that means people paid full money in Pohela Boishak (Fig. 10).

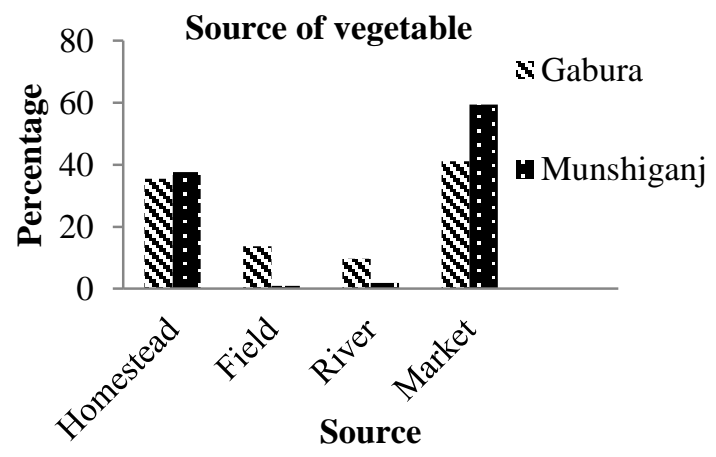

Fig. 8. Source of vegetable for the household

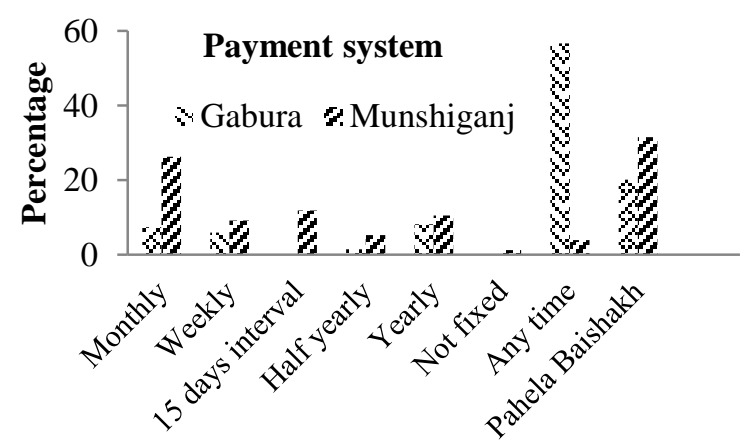

Fig. 10. Paid time to the shopkeeper

some families took it. Rice, fish and vegetables were the main food in the study area but meat, milk and egg were rare because domestic animals did not survive for their natural food due to indirectly effect of soil salinity. It was observed that most of the households (31.67\%) ate rice and fish only at breakfast, other sides, $45.83 \%$ ate rice, fish and vegetable at lunch (Table 5). 
Table 4. Food consumption pattern of women opinion by percentage in the study area

\begin{tabular}{|c|c|c|c|c|c|c|}
\hline \multirow[b]{2}{*}{ Food item } & \multicolumn{6}{|c|}{ Number of women $(\mathrm{N}=120)$} \\
\hline & Daily & Weekly & Monthly & $\begin{array}{c}\text { Special } \\
\text { occasion }\end{array}$ & Never & $\begin{array}{c}\text { Row } \\
\text { percentage }\end{array}$ \\
\hline Rice & $100 \%$ & $0 \%$ & $0 \%$ & $0 \%$ & $0 \%$ & $100 \%$ \\
\hline Vegetable & $79.2 \%$ & $19.8 \%$ & $0 \%$ & $0 \%$ & $0 \%$ & $100 \%$ \\
\hline Fish & $78.33 \%$ & $8.33 \%$ & $8.33 \%$ & $3.33 \%$ & $0 \%$ & $100 \%$ \\
\hline Bread & $1.67 \%$ & $5 \%$ & $9.17 \%$ & $36.67 \%$ & $47.5 \%$ & $100 \%$ \\
\hline Egg & $0.83 \%$ & $49.17 \%$ & $35.83 \%$ & $11.67 \%$ & $2.5 \%$ & $100 \%$ \\
\hline Milk & $0.83 \%$ & $0 \%$ & $6.67 \%$ & $13.33 \%$ & $79.17 \%$ & $100 \%$ \\
\hline Meat & $0 \%$ & $13.33 \%$ & $71.67 \%$ & $13.33 \%$ & $1.67 \%$ & $100 \%$ \\
\hline
\end{tabular}

Table 5. Food habit pattern of women by percentage in the study area

\begin{tabular}{|l|c|c|c|}
\hline Food item & Breakfast (\%) & Lunch (\%) & Supper (\%) \\
\hline Rice + Pulse & 20.83 & 29.17 & 16.67 \\
\hline Rice + Fish + Vegetable & 23.33 & 45.83 & 40.00 \\
\hline Stale Rice + Onion & 10.00 & 0.00 & 1.67 \\
\hline Rice + Fish only & 31.67 & 25.00 & 34.17 \\
\hline Bread vegetable & 14.17 & 0.00 & 7.50 \\
\hline Total & 100.00 & 100.00 & 100.00 \\
\hline
\end{tabular}

\section{Cause of low food intake}

It was showed that causes of low in taking food by the respondents were unavailability of food $(14 \%)$, salinity $(13 \%)$, high price $(13 \%)$ and others associated problems $(50 \%)$, respectively (Fig. 11). Salinity intrusion due to reduction of freshwater flow from upstream, salinisation of groundwater and fluctuation of soil salinity were major concern of Bangladesh. Tidal surge bring in saline water inside the polders in the coastal area. Due to drainage congestion, the area remained waterlogged, increasing the salinity and its impact on vegetation, plants and overall agriculture (Abedin, 2010).

\section{Food scarcity}

From the field survey, it was observed that food insecurity was occurred in the month of Ashin, Kartik and Agrahayan. Fig. 12 indicated the causes of food insecurity by the respondents such as soil salinity (20\%), lack of storage foods (12\%), market was so far $(10 \%)$, no homestead fruits and vegetables $(5 \%)$ and lack of open space for cultivation (4\%), respectively. About $17 \%$ household said that they were not found enough fish in river and increased price was the another cause.

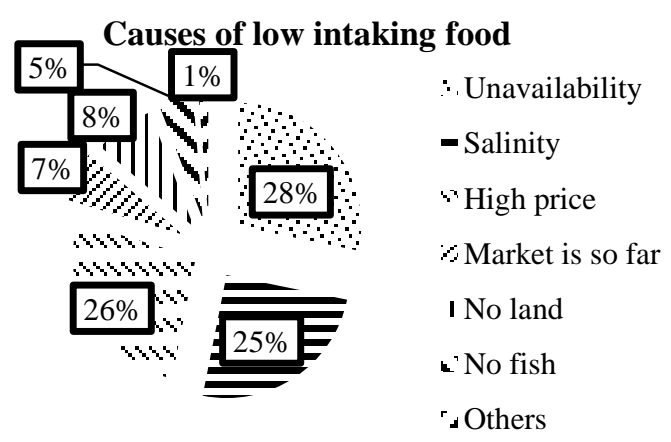

Fig. 11. Causes of low in taking food of women

\section{Disease of women}

Fig. 13 focused that at present time, 33.81\% respondents were affected by diarrhea, dysentery $(20.50 \%)$, skin disease (36\%), warms $(2 \%)$ and Jandis (3\%) respectively. Kangalawe (2012) observed in coastal region that diarrheal disease and respiratory infection were the most frequently climate-related diseases among the community.

\section{Treatment methods of disease}

From the survey result, it was found that about $59.01 \%$ respondents went to village doctor for their health treatment; another side $8.19 \%$ people went to clinic (Govt. + NGO). About 1.63 percent respondents did not receive any treatment (Fig. 14). Hygiene behavior and the prevention of water and sanitation-related disease were influenced by socio-economic factors, such as proper housing, nutrition, clothing and education. Better nutrition provided a barrier against disease transmission. Education may help to develop hygienic behaviors (Ahmed and Rahman, 2000). The government institutions included one Upazila Health Complex and four family Planning center in the study area.

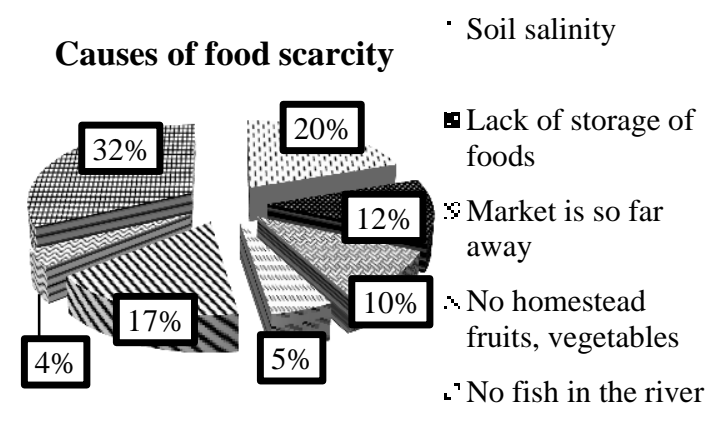

Fig. 12. food scarcity of the household 


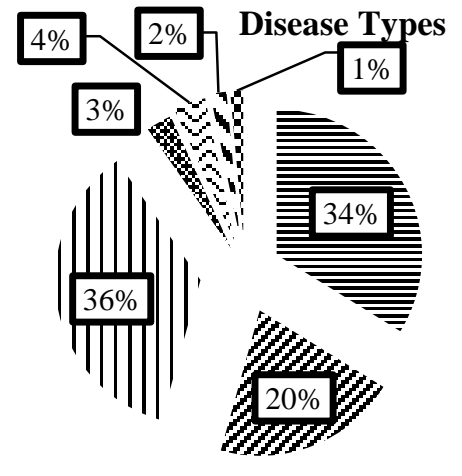

Fig. 13. Diseases of the women

\author{
= Diarrohea \\ Dysentry \\ I Skin disease \\ Typhoid \\ Q Jandis \\ Warms \\ Others
}

\section{Conclusions}

Salinity was the principal source of food insecurity in the coastal region of Bangladesh indirectly affecting the nutritional status of the coastal people. The mean height of the respondents was $142.46 \mathrm{~cm}$ and about $54.17 \%$ women had BMI 18.5-24.9 that means normal BMI category. It was evident that malnutrition status which decreases with increasing educational status among the women in the study area. About $79.16 \%$ families had vegetable gardens around their houses and they were gardening for feeding of the family and selling for additional money. They paid their due loan (money) in Pohela Boishakh Skin disease (36\%) and diarrhea was most of the frequently disease in the study area. About

\section{References}

Abedin, M. Z. 2010. Global Warming, Climate Change and Impact on Agriculture in Bangladesh, $4^{\text {th }}$ National Convention of Krishibid Institute, Bangladesh.

Ahmed, F. M. and Rahman, M. M. 2000. Water Supply \& Sanitation.ITN BANGLADESH.Center for Water Supply and Waste Management, BUET.Dhaka, Bangladesh.

Cooper, E. 1991. Intestinal parasitoses and the modern description of diseases of poverty, Trans R SocTrop Med, 85, pp.168-170.

Esterik Van, P. 1984. Intra-family food distribution its relevance for maternal and child nutrition. In Prepared for the maternal and child health amendment to the Cornell Nutritional Surveillance Program, No. 18.

Islam, M. R; Ahmad, M; Huq, H. and Osman, M. S. 2006. "State of the Coast", ICZMP project, WARPO, Dhaka.

Kangalawe, R.Y. M. 2012. Food security and health in the southern highlands of Tanzania: A multidisciplinary approach to evaluate the impact of

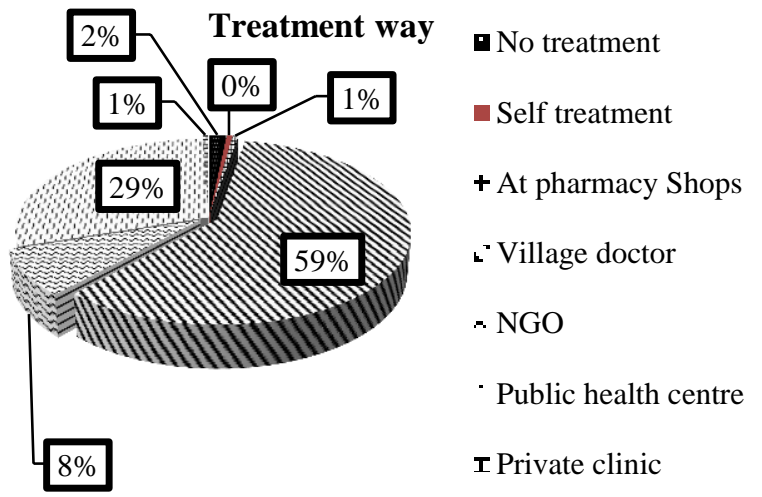

Fig. 14. Treatment way of the women

$59.01 \%$ respondents went to village doctor for their health treatment but 1.63 percent respondents did not receive any treatment. People ate less amount of food than before because of unavailability of foods due to salinity problem. Most of the women were malnourished due to appropriate food availability. They were spending a lot of money for their health treatment of various diseases. Findings of this study will help the policy makers, local government officials and community leaders to combat existing and future threat of climatic and human induced impacts. So it will need more time to recover the associated problems of Aila in the study area.

climate change and other stress factors, African Journal of Environmental Science and Technology 6, doi: 10.5897/ajest11.003,pp50-66.

National Capacity Self-Assessment (NCSA). 2007. Ministry of Environment and Forest, Government of the people's Republic of Bangladesh.

National Institute of Population Research and Training (NIPORT). 2009.Banladesh Demographic and Health Survey.

Pena and Bacallao. 2002. Malnutrition and poverty, Annu Rev Nutr, (22),pp241- 253.

UNICEF. 1998. The state of the world's children, Geneva.Oxford University Press.

WHO. 2000. Obesity: Preventing and managing global epidemic. TRS. Geneva.

WHO/SEARO. 2000. Women of South-East Asia.A health profile, World Health Organization. Regional Office for South-East Asia, New Delhi.

World Bank. 2008. Whispers to Voices: Gender and Social Transformation in Bangladesh. 